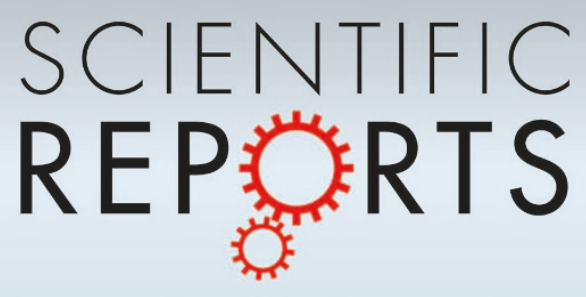

OPEN

SUBJECT AREAS:

CLIMATE SCIENCES

CLIMATE CHANGE

CRYOSPHERIC SCIENCE

CLIMATE AND EARTH SYSTEM

MODELLING

Received

26 February 2013

Accepted

13 June 2013

Published

2 July 2013

Correspondence and requests for materials should be addressed to S.H. (stephan. harrison@exeter.ac.

uk)

\section{Rapid thinning of the late Pleistocene Patagonian lce Sheet followed migration of the Southern Westerlies}

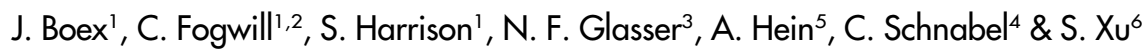

${ }^{1}$ College of Life and Environmental Sciences, University of Exeter, Exeter, EX4 4R, UK, ${ }^{2}$ Climate Change Research Centre, University of New South Wales, Sydney, New South Wales, Australia, ${ }^{3}$ Institute of Geography and Earth Science, Aberystwyth University, Aberystwyth, Wales, SY23 3DB, ${ }^{4}$ NERC Cosmogenic Isotope Analysis Facility, SUERC, East Kilbride, G75 OQF, UK, ${ }^{5}$ School of GeoSciences, University of Edinburgh, Edinburgh, ScotlandUK, ${ }^{6}$ Scottish Universities Environmental Research Centre (SUERC), Scottish Enterprise Technology. Park, East Kilbride, UK G75 OQF.

Here we present the first reconstruction of vertical ice-sheet profile changes from any of the Southern Hemisphere's mid-latitude Pleistocene ice sheets. We use cosmogenic radio-nuclide (CRN) exposure analysis to record the decay of the former Patagonian Ice Sheet (PIS) from the Last Glacial Maximum (LGM) and into the late glacial. Our samples, from mountains along an east-west transect to the east of the present North Patagonian Icefield (NPI), serve as 'dipsticks' that allow us to reconstruct past changes in ice-sheet thickness, and demonstrates that the former PIS remained extensive and close to its LGM extent in this region until $\sim 19.0 \mathrm{ka}$. After this time rapid ice-sheet thinning, initiated at $\sim 18.1 \mathrm{ka}$, saw ice at or near its present dimension by $15.5 \mathrm{ka}$. We argue this rapid thinning was triggered by a combination of the rapid southward migration of the precipitation bearing Southern Hemisphere $(\mathrm{SH})$ westerlies and regional warming.

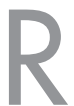
econstructing the timing and rate of decay of the Earth's ice sheets since the Last Glacial Maximum (LGM) allows us to assess the mechanisms of climate change globally during a major climate transition ${ }^{1,2}$. This provides crucial information for testing climate models, and helps us better predict the response of modern ice sheets to future climate change. Of particular value are reconstructions of the rate and timing of glacier changes regionally and globally during the last glacial to interglacial transition, as these provide insights into global climatic hemispheric teleconnections, the mechanisms by which external climate forcing are transmitted through the Earth's climate system ${ }^{3}$.

Establishing if the onset of deglaciation was synchronous globally allows detailed assessment of the relative roles of atmospheric and oceanic circulations as drivers of climate change. An atmospheric driver is suggested from high resolution synchrony between the Earth's climatic systems of the northern and southern hemispheres and implied from the comparison of glacial and palaeoecological records at many mid latitude sites which closely follow changes recorded in the Greenland ice core records ${ }^{4,5}$. Alternatively, an oceanic driver of climate signalling at this time is suggested from comparison with Antarctic ice core records, and mid to high latitude sites in Southern Patagonia, suggesting that during the glacial-interglacial transition there may have been asynchronous behaviour in the climate systems of the two hemispheres ${ }^{6-8}$.

Resolution of the debate is important because of the light it sheds on the mechanisms of climate change. If glacier and palaecological changes on millennial and sub-millennial scales are in phase in both hemispheres, then this points to the dominance of atmospheric circulation mechanisms of climate change. If, on the other hand, the fluctuations are out of phase, then it suggests the operation of an oceanic bipolar seesaw linked to the thermohaline circulation that causes warm conditions in the north to coincide with cold oceanic conditions in the south and vice versa ${ }^{8}$. Other, regional factors may also play a role, including the suggestion that regional warming was caused by $\mathrm{CO}_{2}$ release from the Southern Ocean triggered by insolation-driven Antarctic sea ice retreat ${ }^{9}$. Testing these hypotheses will improve our understanding of the sensitivity of these ice sheets to past and future climate forcing, and is critical to understanding the global drivers of climate change ${ }^{3}$. In order to do this, however, a more complete record of the behaviour of mid-latitude Southern Hemisphere ice sheets through time will be needed than has been achieved so far. In working towards this goal we present here the first three-dimensional reconstruction of a major outlet of one of the former Southern Hemisphere $(\mathrm{SH})$ mid-latitude ice sheets. Our focus is 


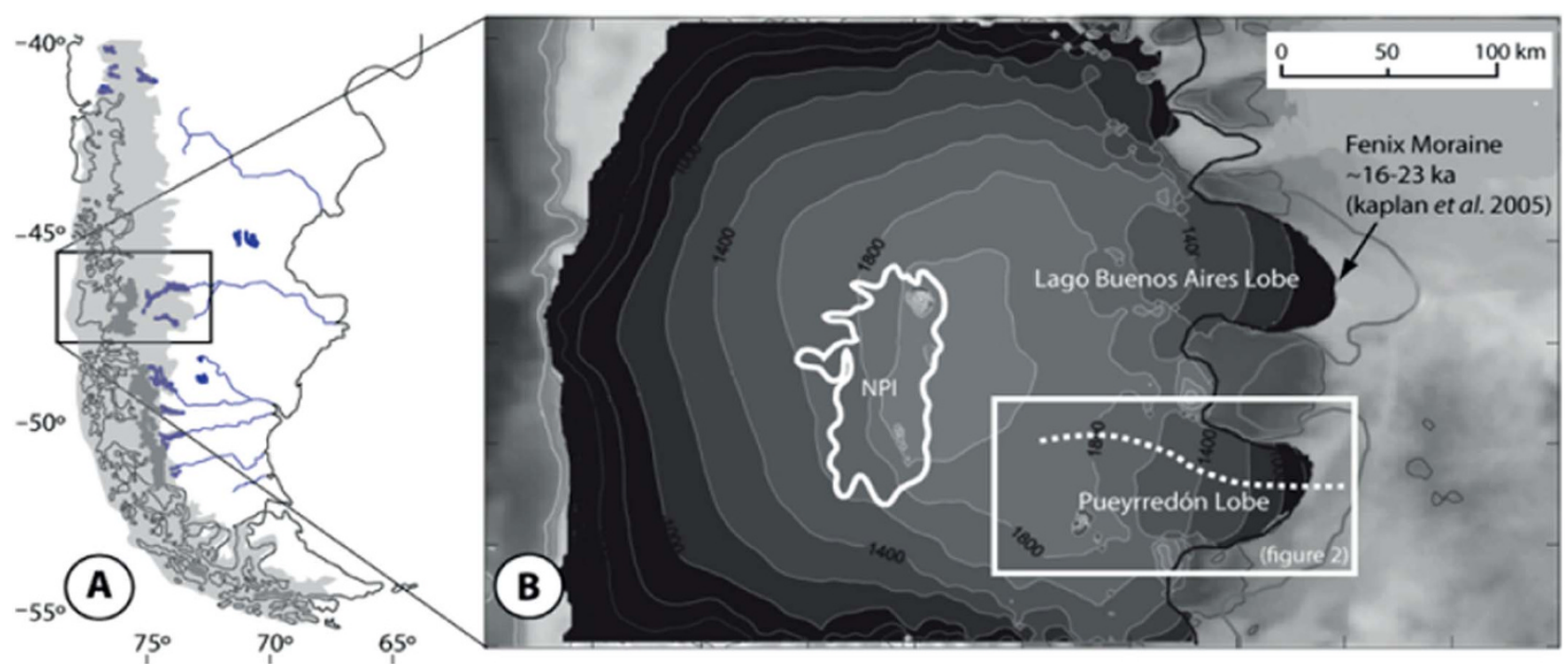

Figure 1 Location map; Map A, South America and the location of the study area also showing the existing North and South Patagonian Icefields (dark grey) together with the mapped LGM ice sheet (light grey) ${ }^{11}$. Map B is adapted from ${ }^{17}$ and shows the modelled ice thickness based on mapped outer limits in the Lago Buenos Aires Lobe. The white box shows the location of the study area and transect that forms the focus of this study (see Figure 2).

the Pleistocene PIS during the LGM and understanding its evolution provides insight into the role of the $\mathrm{SH}$ climate system during deglaciation.

The Patagonian Icefields consist of two separate ice masses, the NPI and South Patagonian Icefield (SPI). They are the largest temperate ice masses on Earth and their outlet glaciers are some of the most dynamic. The icefields are nourished by precipitation from the Southern Hemisphere westerlies and their dynamics are controlled by seasonal variations in the westerlies and associated ocean currents $^{4,10}$. Geomorphological and chronological evidence shows that during the late Quaternary the Patagonian Icefields coalesced to form the PIS over the Southern Andes ${ }^{11}$ (Figure 1). Over the past eighty years researchers have mapped and dated the limits of the ice sheet providing firm constraints on its lateral extent during multiple glacial phases throughout the Quaternary ${ }^{1-14}$. This makes it the ideal location to assess the forcing mechanisms of climate driven glacial change in the Southern Hemisphere. However whilst past work has established the extent and timing of ice sheet advances these lateral constraints do not allow us to reconstruct changes in the vertical extent and volume of the ice sheet ${ }^{14-16}$. This latter information is crucial to help us understand the nature of climate forcing and ice sheet response, and the contribution of the ice sheet to past sea level rise.

Geomorphological evidence indicates that fast-flowing outlet glaciers occupied both the Lago Buenos Aires valley and Lago Pueyrredón basin; two major ice discharge routes of the PIS. In the Lago Pueyrredón basin two moraine systems, the Río Blanco and Hatcher moraines, have been dated by CRN methods to the LGM and MIS 8 (260 ka), respectively ${ }^{13,15}$. The Río Blanco moraines were deposited between $29 \mathrm{ka}$ and $21 \mathrm{ka}$ and mark the horizontal LGM extent in this area ${ }^{13,15,16}$. The age for the Hatcher moraines was determined from outwash cobbles to $260 \mathrm{ka}^{15}$. Fast-flowing glaciers played a key role in effectively drawing down the main central icemass with outlet lobes characterised by low surface gradients and inferred low basal shear traction associated with basal sliding. High spatial resolution three-dimensional ice sheet models of central Patagonia ${ }^{17}$ at the LGM show a 'highly dynamic, low angled ice sheet' which was drained by large ice streams to the east and west and with a mean ice thickness of $\sim 1130 \mathrm{~m}$. The modelled ice sheet was considered 'thin' when compared to previous regional-scale modelling reconstructions of the PIS at the $\mathrm{LGM}^{18}$. The modelling result ${ }^{17}$ agrees with geomorphic interpretations showing fast-flowing outlet glaciers drained the eastern margins of the former ice sheet ${ }^{11}$ (Figure 1).

Whilst the horizontal ice limits are reasonably well established for large parts of the LGM PIS, there are no reconstructed ice limits to constraint its vertical extent or ice surface profile. This has hindered reconstructions of past ice sheet volume and rate of decay and our ability to test the impact of climate on ice volume through time, critical to understanding ice sheet dynamic processes. To derive detailed chronological constraints on late Quaternary ice surface elevation changes we targeted mountains thought to have protruded through the ice sheet above the Pueyrredón Lobe ${ }^{17}$. Our study site forms a west-east transect extending from Cerro Tamango $(1722 \mathrm{~m}$; $\left.47^{\circ} 10^{\prime} 06.87 \mathrm{~S} ; 72^{\circ} 34^{\prime} 30^{\prime \prime} \mathrm{W}\right)$ in the west, through Cerro Oportus (2076 m; $47^{\circ} 07^{\prime} 14^{\prime \prime} \mathrm{S} ; 7^{\circ} 07^{\prime} 53^{\prime \prime} \mathrm{W}$ ) to Sierra Colorado (1537 m; $47^{\circ} 22^{\prime} 05^{\prime \prime} \mathrm{S} ; 71^{\circ} 37^{\prime} 23^{\prime \prime} \mathrm{W}$ ) (Figure 2). The mountains separate the Lago Pueyrredón basin to the south from the Chacabuco Valley to the north. We used geomorphological analysis and CRN exposure analysis on erratic boulders, bedrock and moraine boulders deposited on the mountain flanks to reconstruct the west-east ice-surface profiles. The northern flanks of Cerro Tamango and Cerro Oportus were sampled and these locations record upper ice limits in the Chacabuco Valley. In light of recent CRN calibration rate studies in Patagonia we apply the production rate for the isotopes ${ }^{10} \mathrm{Be}$ and ${ }^{26} \mathrm{Al}$ derived from New Zealand that overlap at 1 sigma with an independently derived production rate from Lago Argentino, Patagonia ${ }^{16,19}$. We present the data across the profile in Figure 2, together with our interpretation of the former ice sheet surface. The full data set is available in Table S1 in the Supplementary Information.

\section{Results}

The uppermost constraint on ice sheet thickness comes from Sierra Colorado where two distinct lateral moraines mark the former ice surface (Figure 2). ${ }^{10} \mathrm{Be}$ and ${ }^{26} \mathrm{Al} \mathrm{CRN}$ exposure ages of 113 to $177 \mathrm{ka}$ were obtained from 3 erratic boulders on the uppermost moraine at $1368 \mathrm{~m}$ altitude. The exposure ages are similar to those obtained from boulders on the Hatcher moraines further east ${ }^{13}$. Based upon the analysis of paired ${ }^{10} \mathrm{Be}$ and ${ }^{26} \mathrm{Al}$ we suggest that the true age of this moraine is in excess of $177 \mathrm{ka}$. The result supports previous mapping and indicates the moraine represents an expansion of the PIS that took place before the last interglacial ${ }^{15}$. The valley floor to the south sits at around $150 \mathrm{~m}$ elevation and thus the PIS was around 1,200 m thick here at this time. 


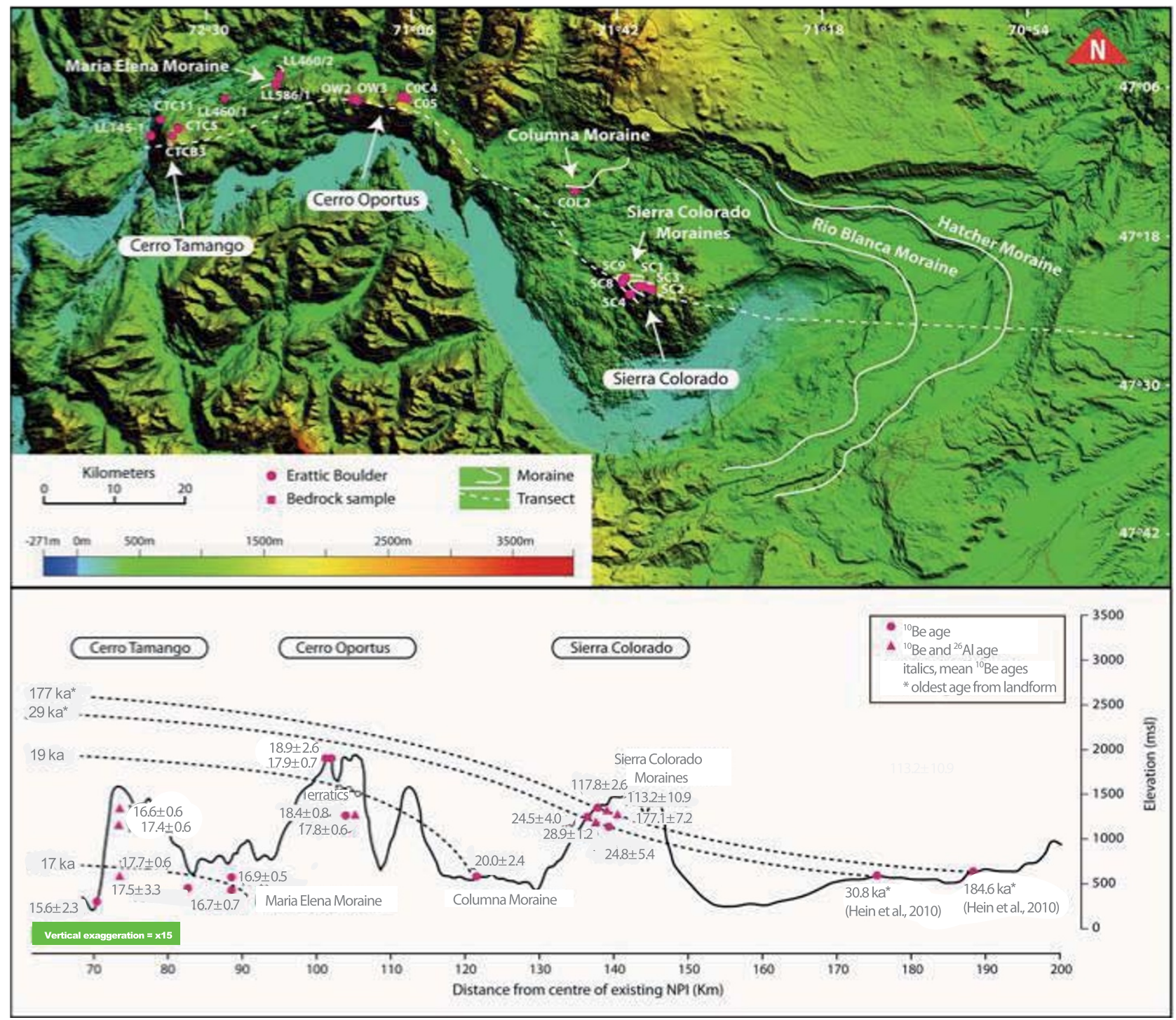

Figure $2 \mid$ Digital elevation model (SRTM) of the Lago Pueyrredón basin showing the study area, transect and reconstructed ice surfaces. The white lines in the east (upper panel) show previously mapped outer limits, the Hatcher and Rio Blanco moraines ${ }^{15}$. Pink dots show the location of cosmogenic exposure age samples, from mountains Cerro Tamango in the west to Cerro Oportus and Sierra Colorado in the east. The white dotted line shows the location of the transect shown in the cross section. The lower panel shows the transect generated from SRTM data with $\mathrm{x} 15 \mathrm{vertical}$ exaggeration (see Figure 1 for location). Sampled boulders are shown with exposure ages (circles show ${ }^{10} \mathrm{Be}$, triangles show both ${ }^{10} \mathrm{Be}$ and ${ }^{26} \mathrm{Al}$ exposure ages).

The age of the lower moraine identified on Sierra Colorado, $100 \mathrm{~m}$ below the uppermost ice- limit gives exposure ages ranging from 24.5-28.9 ka. Based on geomorphological evidence we suggest the oldest sample reflects the most likely age of this moraine. This agrees with the CRN estimates of $28.7 \mathrm{ka}$ for the outermost of the Río Blanco moraines, $190 \mathrm{~km}$ from the centre of the contemporary NPI and $20 \mathrm{~km}$ to the east of Sierra Colorado ${ }^{15,16}$ (Figure 2). These data demonstrate that both the Río Blanco moraine and the lower moraine on Sierra Colorado date to the LGM as previously suggested $^{13,14}$. Our results indicate that the PIS reached a maximum elevation of $1100 \mathrm{~m}$ at the LGM in the vicinity of Sierra Colorado, $120 \mathrm{~km}$ from the centre of the NPI. This estimate agrees well with high-resolution ice-sheet modelling reconstructions ${ }^{17}$ and is supported by erratic CRN exposure ages of $17.9 \pm 0.7 \mathrm{ka}$ and $18.9 \pm$ $2.6 \mathrm{ka}$ from the summit of Cerro Oportus, and this demonstrates the summit remained covered by ice at the LGM. The profile of the ice sheet at this time can be tied to a lateral constraint, the Columna Moraine System ${ }^{13}$ (Figure 2). Based on an exposure age from an erratic on the Columna Moraine system and the exposure ages from the summits of Cerro Oportus we infer that the ice sheet extended horizontally over $120 \mathrm{~km}$ from the centre of the modern NPI at around $20.0 \pm 2.4 \mathrm{ka}$.

Our dating indicates that the summit of Cerro Oportus at $1895 \mathrm{~m}$ altitude was exposed at around $\sim 19.0 \mathrm{ka}$, with a stepped lowering of the ice surface to $1300 \mathrm{~m}$ altitude at $\sim 18.1 \mathrm{ka}$. After this time we record rapid exposure of the full altitudinal profile of Cerro Tamango and Oportus, suggesting rapid thinning after $18 \mathrm{ka}$, with over $1000 \mathrm{~m}$ of vertical thinning of the former ice sheet within approximately 1000 years. This interpretation of rapid deglaciation is well constrained by three combined ${ }^{10} \mathrm{Be} /{ }^{26} \mathrm{Al}$ analyses, which are internally consistent (Figure 2). After this period of rapid ice sheet drawdown, there was a brief and limited readvance, recorded at the Maria Elena Moraine at around $17 \mathrm{ka}$, and this demonstrates that ice was present in the Chacabuco Valley at this time.

\section{Discussion}

Our constraints on the LGM and lateglacial deglaciation record shows the PIS response to climate forcing through this important 


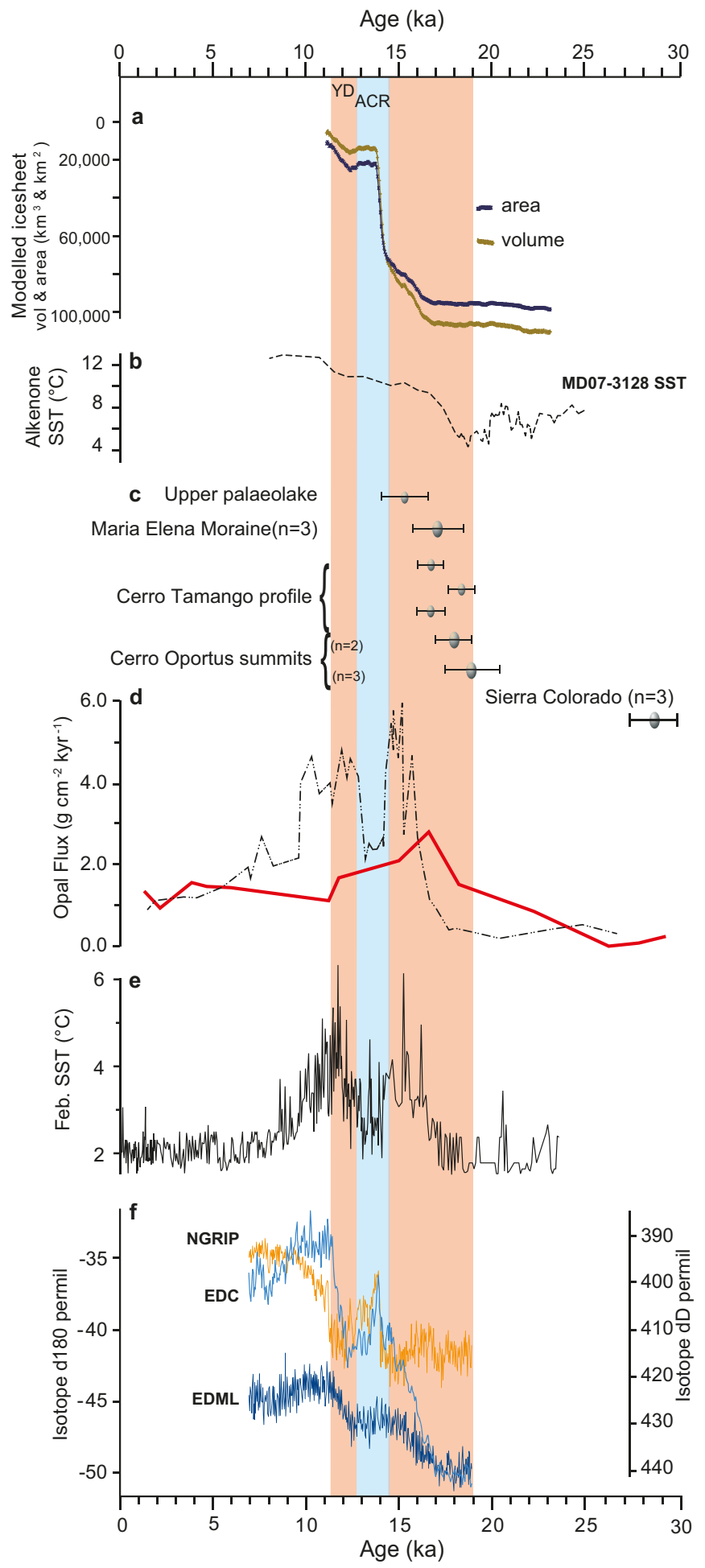

Figure $3 \mid$ Deglacial records illustrating the rapid thinning of the Patagonian Ice Sheet at $47.1^{\circ} \mathrm{S}$ against warming and rising atmospheric $\mathrm{CO}_{2}$ in Antarctica, upwelling in the Southern Ocean and NGRIP ice core record $^{22}$. (a) Time-series of ice sheet volume and area during deglaciation from the optimum LGM extent at 23,500 through to 11,000 years driven by ELA re-scaled from the Vostok temperature reconstruction ${ }^{22}$ Periods of warming in Antarctica are highlighted in red, while the Antarctic Cold Reversal (ACR) is highlighted in blue and the Younger Dryas (YD) is in grey. (b) Alkenone-based SST reconstruction from core MD07-3128 $\left(53^{\circ} \mathrm{S}\right)^{28}$. (c) Accepted exposure ages for ice sheet stages, marking the changing volume and extent of the ice sheet in the Lago Pueyrredón basin and the Chacabuco Valley calculated with the independently derived NZ production rate $\mathrm{r}^{16,19}$. (d) Opal flux from ocean cores TN057-13PC $\left(51^{\circ} \mathrm{S}\right.$, $\left.4^{\circ} \mathrm{E}\right)$ and NBP9802-6 $\left(62^{\circ} \mathrm{S}, 169^{\circ} \mathrm{W}\right)$ as a proxy for upwelling in the Southern Ocean ${ }^{22}$. Opal flux and February SST are plotted on the published age model for TN057-13PC ${ }^{32}$. (e) February SST estimated by applying the modern analog technique ${ }^{30,31}$ to diatom species assemblages extracted from TN057-13PC ${ }^{33,34}$. (f) Ice isotope chronologies for the EPICA Dome C (EDC) and EPICA Draunning Maud Land (EDML) core (light and dark blue respectively), and North Greenland Icecore Project (NGRIP) core (orange) $)^{35}$.

climate transition, with initial retreat after $29.0 \mathrm{ka}$ and the ice sheet remaining close to its LGM dimension until $\sim 19$ ka (see Figure 3 AE). Data from Cerro Oportus and Cerro Tamango indicate stepped thinning between $19 \mathrm{ka}$ and $18.1 \mathrm{ka}$, followed by rapid thinning throughout the altitudinal profile until a brief still stand or advance at around $16.9 \mathrm{ka}$. Evidence from a series of former ice-dammed lakes within this limit (Figure 3D) suggests that ice had withdrawn rapidly to within $10-15 \mathrm{~km}$ of its present extent by $15.6 \mathrm{ka}^{13}$ There is no evidence here of a substantial readvance in the Lago Pueyrredón basin related to either the Antarctic Cold Reversal (ACR) or The Younger Dryas (YD). Subsequent expansion of the ice sheet during the late glacial served only to dam westwards drainage to the Pacific, leading to the establishment of a series of lakes filling the basins to the east of the present day $\mathrm{NPI}^{11,13}$.

This direct record of large-scale rapid thinning of the ice sheet between 19.0 and 15.6 ka clearly highlights the sensitivity of the PIS at this latitude to changing climate (Figure 3a, c). Our observations have two important implications. Firstly, they support high resolution ice-sheet models ${ }^{17}$ with respect to the rate of ice sheet decay through the Last Glacial-Interglacial Transition (Figure 3F), and emphasise the key role fast flowing outlet glaciers played in effectively drawing down the main central ice mass ${ }^{17}$. Secondly, even with the uncertainties in the data the timing of this thinning is coincident with marked changes in both the $\mathrm{SH}$ oceanic and atmospheric systems. We can suggest several hypotheses that can account for this pattern of ice sheet thinning. In particular thinning coincides with marked warming of SH mid to high latitudes, that has been linked to changes in ocean thermohaline circulation, specifically warming of the southern ocean - the bipolar seesaw - thought to be triggered either by spring insolation changes combined with variations in greenhouse gas fluxes ${ }^{20}$ or by ocean circulation changes due to increased melt water from the Northern Hemisphere ice sheets at ca. $19 \mathrm{ka}^{2,20,23,27}$. Although SST changes between MIS 4-2 played a significant role in driving the evolution of the PIS, its behaviour lagged SST. The reasons for this are unclear but probably relate to changes in ice dynamics ${ }^{21}$. However, concurrent to this regional warming there is also physical evidence ${ }^{22}$ of a rapid southward latitudinal shift of the precipitation bearing Southern Hemisphere Westerlies (SHW). This is particularly evident in cores in the SE Pacific at this time ${ }^{23,24}$ (Figure 3A-D).

Regional evidence for this marked atmospheric shift comes from marine records south of the Antarctic Polar Front $\left(53.2^{\circ}-61.9^{\circ} \mathrm{S}\right)$ off the southern Chilean margin that record increased opal accumulation and Alkenone-based reconstructions linked to enhanced upwelling during the late glacial (Figure $3 \mathrm{~b}$ and $\mathrm{d}$ ). It is suggested that this enhanced upwelling was triggered as the core of the SH westerlies migrated rapidly southwards from their LGM position. Whilst debate remains over the exact timing marine records suggest that southern migration was initiated at around $\sim 17 \mathrm{ka}^{24}$, and the SH westerlies shifted rapidly south and stabilised at $\sim 15.5 \mathrm{ka}$, by which time they may well have reached $62^{\circ} \mathrm{S}$ in the SE Pacific ${ }^{1,25}$, (Figure $3 \mathrm{~d})^{23}$. A southward shift in the SH westerlies would have warmed the Southern Ocean and Antarctica ${ }^{22}$ by allowing degassing of $\mathrm{CO}_{2}$ to the atmosphere and providing a positive feedback to initial warming ${ }^{26,27}$. This poleward shift would have also significantly reduced precipitation in the vicinity of the current NPI, and we 
propose that this reduction in precipitation in conjunction with regional warming amplified the rapid ice sheet decay that we record (Figure 3e,f). This suggestion is further supported by climate modelling studies that predict significant increases in precipitation at the LGM in NW Patagonia ${ }^{24}$. However, recent work ${ }^{28}$ has found that oceanic changes associated with the bi-polar seesaw was sufficient to explain glacier recession and ELA rise in southern Patagonia during late glacial times, and they argue against the shift in the Southern Westerlies as a trigger for deglaciation. This may not be the case in central Patagonia however. Glasser et al. ${ }^{29}$ dated Younger Dryas age moraines at the mouths of several valleys around the NPI, suggesting this argues against a bipolar seesaw operating at these latitudes during this time. Clearly, this issue is not yet resolved ${ }^{30}$.

Our findings highlight the sensitivity of central Patagonia to climate change which during Pleistocene times may have been communicated via regional warming and shifts in the latitude of the $\mathrm{SH}$ westerlies. We argue that the latitudinal variation in the core of the precipitation bearing $\mathrm{SH}$ westerlies is probably key to defining the extent and magnitude of glaciation at these latitudes, although the pattern to the south may have different causes. Our results have important implications for glaciers and hydrological systems in Patagonia if, as predicted, westerly airflow continues to migrate polewards as a result of a warming climate ${ }^{27}$. Our approach using mountains to record the three-dimensions of the former ice mass makes important steps towards aligning the geomorphology of Patagonia with ice sheet and climate modelling based studies, and provides critical new insights on the sensitivity of this region to climate change $^{31}$.

\section{Methods}

In order to reconstruct the three-dimensional evolution of the PIS in the study area we used geomorphological analysis to ground-truth the landform mapping from satellite imagery, maps from the Institute Geographical Militar of Chile, Landsat imagery and aerial photographs. The chronology of ice sheet thinning was obtained using glacial erratics and glacially eroded bedrock which were sampled from key landforms and altitudinal profiles for CRN exposure analysis using ${ }^{10} \mathrm{Be}$ and ${ }^{26} \mathrm{Al}$ (see SOM and Figure 2).

Samples for CRN were used to constrain the age of moraines or ice sheet trimlines and also to reconstruct the timing of ice sheet thinning and mountain top exposure. Samples were taken from stable boulders and bedrock surfaces and around half a kilogram of whole rock was required for analysis. Samples were processed at the laboratories at the NERC CIAF at SUERC and at the University of Exeter. Crushing was followed by mineral separation and chemical etching to produce clean quartz. The quartz was then dissolved in order to chemically extract and separate ${ }^{10} \mathrm{Be}$, and for seven samples ${ }^{26} \mathrm{Al}$. The extracted isotopes were then measured by AMS at SUERC. Results for ${ }^{10} \mathrm{Be}$ and ${ }^{26} \mathrm{Al}$ concentrations were converted to exposure ages using the CRONUS-Earth online calculator, version 2.2 using the NZ Macaulay landslide, NZ calibration data set (Supplementary Table S2). The Dunai time varying model is used for the data presented here to allow direct inter-comparison with previous studies (see SOM for details of this). No correction was made for erosion, snow cover or isostatic uplift in this study and therefore the exposure ages presented are minimum ages.

1. Denton, G. H. et al. The Last Glacial Termination. Science 328(5986), 1652-1656 (2010).

2. Sime, L. C. et al. Southern Hemisphere westerly wind changes during the Last Glacial Maximum: model-data comparison. Quat. Sci. Rev. 64, 104-120 (2013).

3. Clark, P. U. et al. The Last Glacial Maximum. Science 325(5941), 710-714 (2009).

4. Denton, G. H. et al. Interhemispheric linkage of paleoclimate during the last glaciation. Geogr. Ann. 81A(2), 107-153 (1999).

5. Schaefer, J. M. et al. Near-synchronous interhemispheric termination of the last glacial maximum in mid-latitudes. Science 312(5779), 1510-1513 (2006).

6. Blunier, T. \& Brook, E. J. Timing of millennial-scale climate change in Antarctica and Greenland during the last glacial period. Science 291(5501), 109-112 (2001).

7. Fogwill, C. J. \& Kubik, P. W. A glacial stage spanning the Antarctic Cold Reversal in Torres del Paine $\left(51^{\circ} \mathrm{S}\right)$, Chile, based on preliminary cosmogenic exposure ages. Geogr. Ann. 87A(2), 403-408 (2005).

8. Clark, P. U. et al. The role of the thermohaline circulation in abrupt climate change. Nature 415, 863-869 (2002).

9. Stott, L. A. Timmermann \& R. Thunell, Southern Hemisphere and deep-sea warming led deglacial atmospheric $\mathrm{CO}_{2}$ rise and tropical warming. Science 318, 435-438 (2007).

10. Ackert, R. P. et al. Patagonian glacier response during the late glacial-holocene transition. Science 321(5887), 392-395 (2008).
11. Glasser, N. F. et al. The glacial geomorphology and Pleistocene history of South America between 38 degrees S and 56 degrees S. Quat. Sci. Rev. 27(3-4), 365-390 (2008).

12. Kaplan, M. R. et al. Cosmogenic nuclide chronology of pre-last glacial maximum moraines at Lago Buenos Aires, 46 degrees S, Argentina. Quat. Res. 63(3), 301-315 (2005)

13. Hein, A. S. et al. The chronology of the Last Glacial Maximum and deglacial events in central Argentine Patagonia. Quat. Sci. Rev 29(9-10), 1212-1227 (2010).

14. Kaplan, M. R. et al. Southern Patagonian glacial chronology for the Last Glacial period and implications for Southern Ocean climate. Quat. Sci. Rev 27(3-4), 284-294 (2008)

15. Hein, A. S. et al. Middle Pleistocene glaciation in Patagonia dated by cosmogenicnuclide measurements on outwash gravels. Earth Planet. Sci. Lett. 286(1-2), 184-197 (2009).

16. Kaplan, M. R. et al. In-situ cosmogenic ${ }^{10} \mathrm{Be}$ production rate at Lago Argentino, Patagonia: Implications for late-glacial climate chronology. Earth Planet. Sci. Lett. 309(1-2), 21-32 (2011)

17. Hubbard, A. et al. A modelling reconstruction of the last glacial maximum ice sheet and its deglaciation in the vicinity of the Northern Patagonian Icefield, South America. Geogr. Ann. 87A(2), 375-391 (2005).

18. Hulton, N. R. J. et al. The Last Glacial Maximum and deglaciation in southern South America. Quat. Sci. Rev 211, 233-241 (2002).

19. Putnam, A. E. et al. In situ cosmogenic ${ }^{10} \mathrm{Be}$ production-rate calibration from the Southern Alps, New Zealand. Quat. Geochron. 5(4), 392-409 (2010).

20. Kilian, R. \& Lamy, F. A review of Glacial and Holocene paleoclimate records from southernmost Patagonia $\left(49-55^{\circ}\right.$ S). Quat. Sci. Rev. 53, 1-23 (2012).

21. Lamy, F. et al. Antarctic timing of surface water changes off Chile and Patagonian ice sheet response. Science 304, 1959-1962 (2004).

22. Anderson, R. F. et al. Wind-Driven Upwelling in the Southern Ocean and the Deglacial Rise in Atmospheric $\mathrm{CO}_{2}$. Science 323(5920), 1443-1448 (2009).

23. McCulloch, R. D. et al. Climatic inferences from glacial and palaeoecological evidence at the last glacial termination, southern South America. J. Quat. Sci. 15 (2000).

24. Rojas, M. et al. The Southern Westerlies during the last glacial maximum in PMIP2 simulations. Clim. Dyn. 32, 525-548 (2009).

25. Lamy, F. et al. Modulation of the bipolar seesaw in the southeast Pacific during Termination 1 Earth Planet. Sci. Lett. 259(3), 400-413 (2007).

26. D’Orgeville, M., Sijp, W. P., England, M. H. \& Meissner, K. J. On the control of glacial-interglacial atmospheric $\mathrm{CO}_{2}$ variations by the southern hemisphere westerlies. Geophys. Res. Lett. 37, L21703 (2010).

27. Sijp, W. P. \& England, M. H. Southern Hemisphere westerly wind control over the ocean's thermohaline circulation. J. Clim. 22, 1277-1286 (2009).

28. Murray, D. S. et al. Northern hemisphere forcing of the last deglaciation in southern Patagonia. Geology 40, 631-634 (2012).

29. Glasser, N. F., Harrison, S., Schnabel, C., Fabel, D. \& Jansson, K. N. Younger Dryas and early Holocene age glacier advances in Patagonia. Quat. Sci. Rev 58, 7-17 (2012)

30. Thompson, D. W. J. et al. Signatures of the Antarctic ozone hole in Southern Hemisphere surface climate change. Nat. Geosc. 4, 741 (2011).

31. Caniupán, M. et al. Millennial-scale sea surface temperature and Patagonian Ice Sheet changes off southernmost Chile $\left(53^{\circ} \mathrm{S}\right)$ over the past $60 \mathrm{kyr}$. Paleoceanography 26, 1-10 (2011).

32. Shemesh, A. D. et al. Sequence of events during the last deglaciation in Southern Ocean sediments and Antarctic ice cores. Paleoceanography 17(4) (2002).

33. Crosta, X., Pichon, J. J. \& Burckle, L. H. Application of Modern Analog Technique to marine Antarctic diatoms: Reconstruction of maximum sea-ice extent at the Last Glacial Maximum. Paleoceanography 13 (1998).

34. Crosta, X., Sturm, A., Armand, L. \& Pichon, J. J. Late Quaternary sea ice history in the Indian sector of the Southern Ocean as recorded by diatom assemblages. Mar. Micropaleont. 50 (2004)

35. Lemieux-Dudon, B. et al. Consistent dating for Antarctic and Greenland ice cores. Quat. Sci. Rev 29, 8-20 (2010).

\section{Acknowledgements}

CRN exposure ages were funded by a NERC CIAF Award to J.B., S.H. and C.J.F. C.J.F acknowledges a Royal Society Research Grant. Sample preparation was undertaken at the NERC Cosmogenic Isotope Analysis Facility and the University of Exeter Cosmogenic Isotope Lab. J.B. was supported by a NERC postgraduate studentship to S.H. and C.J.F. acknowledges the support of ARC awards FL100100195 and FT 120100004.

\section{Author contributions}

The original research idea for this work was contributed by S.H. S.H., J.B. and C.J.F. wrote the main manuscript text; figures were prepared by J.B. and C.J.F. Fieldwork was undertaken by J.B., S.H., N.F.G. and A.H. C.S., C.J.F. and S.X. processed and analysed the $\mathrm{CRN}$ data. All authors reviewed the manuscript.

\section{Additional information}

Supplementary information accompanies this paper at http://www.nature.com/ scientificreports 
Competing financial interests: The authors declare no competing financial interests.

How to cite this article: Boex, J. et al. Rapid thinning of the late Pleistocene Patagonian Ice Sheet followed migration of the Southern Westerlies. Sci. Rep. 3, 2118; DOI:10.1038/ srep02118 (2013). cc) (i) $\odot$ This work is licensed under a Creative Commons AttributionBy No No NonCommercial-NoDerivs 3.0 Unported license. To view a copy of this license, visit http://creativecommons.org/licenses/by-nc-nd/3.0 